\author{
Prof. dr hab. Anna ZĄBKOWICZ \\ Instytut Ekonomii, Finansów i Zarządzania, Uniwersytet Jagielloński \\ e-mail: anna.zabkowicz@uj.edu.pl \\ ORCID: 0000-0003-1977-0884
}

DOI: $10.15290 /$ oes.2021.01.103.03

\title{
JAK NIEMCY OBNIŻAJĄ KOSZTY PRACY? EFEKTY DYSTRYBUCYJNE ${ }^{1}$
}

\begin{abstract}
Streszczenie
Cel - To próba wyjaśnienia swoistego paradoksu, jakim jest utrzymywanie przez Niemcy przewagi konkurencyjnej przy stosunkowo wysokich łącznych kosztach pracy. Nie ogranicza się ona do czysto ekonomicznej analizy płac jako kosztów, lecz bierze pod uwagę także koszty pozapłacowe, które system zabezpieczeń społecznych implikuje, ale może także moderować.

Metoda badań - Analiza kosztów pracy polega tu na dezagregacji uwzględniającej sektory gospodarki (w części pierwszej) oraz uczestników systemu zabezpieczeń emerytalnych (w części drugiej). Przedmiotem zainteresowania są symptomatyczne efekty dystrybucyjne.

Wnioski - Międzysektorowy i międzyregionalny rozkład nakładów mierzonych płacowymi kosztami pracy wyjaśnia proces „duszenia” uśrednionych (w skali całej gospodarki niemieckiej) jednostkowych kosztów pracy. Mianowicie, konkurencyjne w skali międzynarodowej branże przemysłu stymulują swoich pracowników za pomocą rosnących płac, jednocześnie neutralizując wzrost kosztów płacowych dzięki przechwytywaniu nakładów zarówno z innych sektorów gospodarki narodowej, jak i z zagranicy. Zajmują one pozycję uprzywilejowaną także w polityce reform emerytalnych, które chronią producentów przed dalszym wzrostem pozapłacowych obciążeń kosztem wzrastającego wkładu pozostałych stron systemu zabezpieczeń emerytalnych, to jest pracowników i budżetu państwa.
\end{abstract}

Słowa kluczowe: sektor dóbr wymiennych, pozapłacowe koszty pracy, system emerytalny

\section{HOW GERMANS CONSTRAIN LABOUR COSTS. DISTRIBUTIVE EFFECTS 2}

\section{Summary}

Purpose - Germany is successful in preserving cost advantage internationally while sustaining relatively high total labour costs. This proposal to explain the paradox does not rely on a purely economic analysis of wage costs but considers also non-wage costs which social security system implies but which can also be moderated by a systemic change.

Research method - The analysis relies on separating economic sectors (part one) and on identifying particular parties within the social security system (part two). It aims at specific distributive effects.

Results - The inter-sector and inter-regional inputs measured by wage costs explain how unit labour costs on average have been pressed down. Namely, competitive industries are able to stimulate their employees by rising wages, and to neutralize the wage-cost increases simultaneously by capturing inputs

1 Artykuł wpłyną 5 listopada 2019 r., zaakceptowano 5 stycznia 2020 r.

2 Article received on 5 November 2019, accepted on 5 January 2020. 
both from other sectors of national economy as well as from abroad. Accordingly, the „exposed” industries seem to be privileged by the policy of pension reforms which protect employers from continuous growth of non-wage costs shifting the burden of contribution to old-age security onto employees and state budget. Thus, the findings go further than Dustmann et al. who served as inspiration for this analysis of distributive effects.

Keywords: tradable sector, non-wage costs, pensions

JEL Classification: F16, J32

\section{Wstęp}

Jeżeli misją państwa kapitalistycznego jest wzrost gospodarki, to państwo niemieckie po II wojnie światowej odniosło niekwestionowany sukces. Gospodarka niemiecka nie tylko stała się na powrót jedną z największych uprzemysłowionych gospodarek świata, ale także - jedną z najbardziej konkurencyjnych.

Główne zagadnienie tego studium stanowi swoisty paradoks. Niemcom udaje się utrzymać cenowa i kosztowa przewagę w wymiarze międzynarodowym, czego niezbitym dowodem są nadwyżki $\mathrm{w}$ handlu z zagranicą utrzymujące się po wojnie przez całe dekady. Dzieje się tak pomimo stosunkowo wysokich pozapłacowych kosztów pracy.

Będziemy się starali rozwikłać ten paraoks, opierając się na przesłance, że o wynikach ekonomicznych decyduja nie tylko nakłady i korzyści, ale także przechwytywanie nakładów i przesuwanie korzyści lub kosztów. Zjawiska tego rodzaju w literaturze określa się jako efekty dystrybucyjne [Stiglitz, 2004]. Inspiracji do podjęcia tego tropu dostarczył artykuł Christiana Dustmanna i jego współpracowników, opublikowany w "Journal of Economic Perspectives", który między innymi prezentuje wyniki analizy kosztów pracy w rozbiciu na różne sektory gospodarki niemieckiej. Idąc tym śladem, omówimy najpierw zmiany kosztów pracy (w tym płac) w Niemczech na przełomie XX i XXI wieku oraz hipotezy odnoszące się do przechwytywania nakładów. Oczywiście nie jest naszym celem wyręczanie czytelnika przez dostarczanie mu streszczenia publikacji tego zespołu, której tytuł ewidentnie wskazuje na znacznie szersze zainteresowania autorów ${ }^{3}$. Będzie on tutaj przywoływany wyłącznie $\mathrm{z}$ uwagi na efekty dystrybucyjne w postaci międzysektorowego i międzyregionalnego przechwytywania nakładów. Gruntowna analiza danych wykonana przez zespół niemieckich badaczy wydaje się rzadkim przykładem takiego podejścia do konkurencyjności kosztowej, na które pragniemy zwrócić uwagę.

Następnie skupimy się na zagadnieniu, czy reformy emerytalne przeprowadzone w tym samym okresie przyczyniły się do zmiany łącznych kosztów pozapłacowych. Szczególnie jednak interesować nas będzie dyspersja obciążeń, czyli ich rozłożenie

\footnotetext{
${ }^{3}$ Jako główne zagadnienie autorzy wskazują rolę instytucji rynku pracy w sukcesie gospodarczym Niemiec zachodnich.
} 
pomiędzy uczestników systemu zabezpieczeń emerytalnych. Istotnym kontekstem powstania artykułu było to, że we współczesnych państwach socjalnych (welfare state) istotną rolę odgrywają także pozapłacowe koszty, które generowane są przez przymus odprowadzania składek na ubezpieczenia społeczne. W publicznie administrowanym segmencie ubezpieczeń społecznych pracodawcy zobowiązani są do odprowadzania składek na specjalne fundusze. Chociaż te kwoty nie są wypłacane pracownikom w formie płac, to jednak uszczuplaja zyski, dlatego traktuje się je jako koszty pracy. Jeżeli zaś wliczane są w ceny, zmniejszają konkurencyjność cenowa oferowanych dóbr i usług. W Niemczech polityka socjalna, a szczególnie zasady emerytalne, których szczodrość okazała się bardzo trudna do powściagnięcia, przerodziły się w długoterminowy wzrost pozapłacowych kosztów pracy. Nie dziwią zatem zorganizowane naciski pracodawców na rzecz ograniczania tego rodzaju kosztów, określanych jako „klin podatkowy”4, które obserwuje się zarówno w Niemczech, jak i w Polsce. Niniejsze studium kosztów pozapłacowych ogranicza się do kosztów generowanych przez ubezpieczenia emerytalne. Ta część opiera się na materiałach pozyskanych między innymi w czasie pobytu studyjnego autorki przy wsparciu Deutche Akademische Austauschdienst i stanowi istotne dopełnienie odpowiedzi na tytułowe pytanie: jak Niemcy obniżaja (łączne) koszty pracy.

Należy zaznaczyć, że praca ta wychodzi istotnie poza inspirację, którą dał jej artykuł Dustmanna i jego współpracowników [2014]. Druga część artykułu, odnosząca się do pozapłacowych kosztów, wydaje się stanowić istotne uzupełnienie analiz jednostkowych kosztów pracy. Podkreślić trzeba, że choć publikacje ekonomistów na temat „klina podatkowego" nie są rzadkie, tutaj analiza prowadzona jest z uwzględnieniem wszystkich stron systemu zabezpieczeń emerytalnych (a nie tylko osób fizycznych, jak np. w: [Mazurek-Chwiejczak, 2016]), co pozwala tłumaczyć efektami dystrybucyjnymi zagadnienie postawione na wstępie. Efekty dystrybucyjne reform uwidaczniają się w zmianie rozkładu obciążeń kosztami składek pomiędzy pracodawców, pracowników i budżet państwa.

Artykuł proponuje potraktować szerokie zagadnienie reform zabezpieczeń emerytalnych w kontekście kosztów produkcji i konkurencyjności międzynarodowej. Nie dajemy sobie zatem prawa do omawiania motywów i rozlicznych skutków reform emerytalnych. W procesie tych reform spotykają się: polityka i ekonomia, problem sprawiedliwości, ograniczania państwa socjalnego, długu publicznego i tym podobne tematy warte gorącej debaty publicznej. Temat artykułu stawia inne pytanie i w związku z tym reformy emerytalne omówimy tylko w stopniu, który wydaje się konieczny dla analizy kosztów pracy i konkurencyjności międzynarodowej. Pomijając retorykę reform adresowaną do przyszłych emerytów, skoncentrujemy się na rozwiązaniach mających znaczenie dla producentów.

\footnotetext{
${ }^{4}$ Użycie określenia ,podatkowy” w odniesieniu do składek na ubezpieczenie społeczne może wynikać z tego, że w klasyfikacji podatków opracowanej na potrzeby OECD składki te zostały zrównane z podatkami w ścisłym tego słowa znaczeniu. Należy jednak mieć w pamięci, że część ekonomistów nie godzi się z takim zrównaniem, wskazując, że składki mają ściśle określony cel (np. składki emerytalne) - w odróżnieniu od podatków zasilających budżet ogólny [Owsiak, 2002].
} 


\section{Koszty pracy i przechwytywanie nakładów}

Przez długi okres niemiecka gospodarka wykazywała trwałe znamiona konkurencyjności kosztowej i cenowej. Dustmann i współpracownicy [2014, rys. 1] $]^{5}$ wykazuja, że w Niemczech jednostkowe koszty pracy po uwzględnieniu wag konkurencji w ostatnich dekadach, a konkretnie w latach 1994-2012, były zdecydowanie najnizsze $\mathrm{w}$ grupie rozwiniętych gospodarek kapitalistycznych i wykazywały tendencję spadkową - w odróżnieniu od analogicznych wskaźników dla największych gospodarek europejskich i gospodarki Stanów Zjednoczonych. Wprawdzie od czasu wybuchu kryzysu w 2008 trend ULC uległ odwróceniu, co pokazuja inne opracowania, jednak eksport z Niemiec miał cenową przewagę nad produktami większości krajów Europejskiej Unii Monetarnej i Walutowej. Chociaż nominalne jednostkowe koszty pracy zwiększały się nieprzerwanie, saldo obrotów bieżących z zagranicą w tym czasie wykazywało nadwyżkę, która urosła do rekordowego poziomu $8 \%$ PKB w 2016 roku [Priewe, 2018, s. 90, 94, wykresy: A1, A9]. Co więcej, indeks cen w eksporcie praktycznie nie rósł przez cały okres 1999-2016, pozostając na poziomie wyjątkowo niskim w strefie euro [Priewe, 2018, s. 19, wykres 1.110] ${ }^{6}$.

Dla wytłumaczenia przyczyn konkurencyjności gospodarki niemieckiej istotna jest analiza rozkładu jednostkowych kosztów pracy opierająca się na dezagregacji na sektory. Centralne znaczenie maja oczywiście tzw. gałęzie „wyeksponowane” w wymianie zagranicznej (exposed industries) lub - ujmując to bardziej kolokwialnie „wystawowe” gałęzie gospodarki. Ich sukcesy na rynkach zagranicznych niekiedy przypisuje się wysoko wykwalifikowanej elicie pracowników [Płóciennik, 2012]. Dalej posuwają się analizy ujawniające, że owe branże „przechwytują” wartość $z$ innych miejsc gospodarki niemieckiej oraz z zagranicy [Dustmann i in., 2014; Priewe, 2018]. Dzięki takiemu podejściu z analizy płac i kosztów, którą zawiera artykuł Dustmanna i współpracowników, a szczególnie z rozrysowania procesów na wykresach, można wyciąnąć niestandardowy wniosek. Mianowicie, utrzymanie jednostkowych kosztów pracy na stosunkowo niskim poziomie w skali całej gospodarki okazało się możliwe dzięki przechwyceniu nakładów pochodzących z innych sektorów krajowych przez sektor dóbr wymiennych (tradable sector). Wiedza odnosząca się do efektów dystrybucyjnych, przekazana poniżej, pochodzi tyleż z komen-

\footnotetext{
${ }^{5}$ Konkretnie wyliczają oni indeks, który „ujmuje roczne zmiany relatywnych jednostkowych kosztów pracy w kraju i w porównaniu do średniej ważonej jego głównych partnerów handlowych przy czym koszty pracy przelicza się na dolary, a wagi dostosowane są corocznie do zmian we wzorcach handlu" [Dustmann i in., 2014, s. 152]. Wszystkie wyliczenia Dustmanna i współautorów, oparte na wartości płac, odnoszą się do Niemiec zachodnich. Autorzy w ten sposób staraja się ominąć silny wpływ, jaki w Niemczech wschodnich miały koszty transformacji po zjednoczeniu kraju.

${ }^{6} \mathrm{Na}$ tym stwierdzeniu musimy poprzestać z braku dobrego wskaźnika pozacenowej konkurencyjności eksportu. W przypadku niektórych krajów, do których zalicza się Niemcy, przewagę konkurencyjną nie mniejszą niż stosunkowo niskie ceny dają czynniki pozacenowe, na przykład te składające się na jakość produktów i warunki dostaw. Żaden z indeksów nie obejmuje jednak wszystkich czynników, którym należałoby przypisać utrzymanie konkurencyjności. Wymienia się ich wiele i żaden nie wydaje się rozstrzygający [zob. Priewe 2018, s. 60-61].
} 
tarzy autorów, co z własnej, czytelniczej analizy wykresów, które okazały się wyjątkowo treściwe.

Dzięki rozbiciu pasma dystrybucji na sektory autorzy pokazują, że aktywność gospodarcza związana z przemysłem i z wymianą zagraniczną była chroniona przed trendem ograniczania wzrostu realnych płac bardziej niż aktywność w sektorach dóbr niewymiennych. W przemyśle dóbr wymiennych przeciętna dzienna płaca realna wręcz rosła w długim okresie [Dustmann i in., 2014, s. 158, rysunek 4]. Natomiast w pozostałych dwóch sektorach, to jest w sektorze usług wymiennych (tradable services) oraz w sektorze dóbr niewymiennych (nontradable sector), płace w ujęciu realnym obniżyły się [Dustmann i in., 2014, s. 157] i tym można tłumaczyć to, że w sumie wzrost płac realnych w przemyśle był zdecydowanie skromny $(8,2 \% \mathrm{w}$ ciagu 11 lat, to jest od 1995 do 2007 roku). Podczas gdy praca w przemyśle dóbr wymiennych była coraz lepiej wynagradzana, średni wynik krajowy w tym samym czasie hamowały wynagrodzenia pracowników najmniej zarabiających, przede wszystkim - osób zatrudnionych w innych sektorach.

Próbując dociec źródeł konkurencyjności międzynarodowej niemieckich producentów, autorzy biorą również pod uwagę transfery związane z transgraniczną wymianą towarów oraz zagraniczne inwestycje bezpośrednie, poświęcając część rozważań otwarciu rynków w Europie Środkowo-Wschodniej. „Nakłady importowane" (imported inputs) z czterech krajów regionu, mianowicie z: Polski, Węier, Czech i Słowacji stanowiły w 2000 roku 8,5\% nakładów niemieckiej gospodarki, co było udziałem wysokim w porównaniu z gospodarką Włoch czy Francji [Dustmann $\mathrm{i}$ in., 2014, s. 159]. Miało to znaczenie w rachunku ekonomicznym umiędzynarodowionych firm niemieckich, ponieważ ceny i płace w czterech wymienionych krajach były znacznie niższe niż w Niemczech, a regulacje rynku pracy bardziej elastyczne. Niemiecki przemysł dóbr wymiennych odniósł korzyści także dzięki przenoszeniu produkcji do Europy Środkowo-Wschodniej, a nie tylko w handlu na tym kierunku?. Korzyści te można widzieć dwojako. Po pierwsze, jako wykorzystanie przewag tamtejszych ekonomicznych warunków pracy i ram prawnych pracy przez niemieckich pracodawców. Wzrost inwestycji zagranicznych w Polsce, na Węgrzech, w Czechach i Słowacji przekładał się na zwiększenie liczby pracowników w zależnych od niemieckich inwestorów firmach, w których płace były znacznie niższe od niemieckich, nie tylko ze względu na niższe koszty utrzymania, ale także wskutek bardziej elastycznych regulacji rynku pracy ${ }^{8}$. Po drugie, na miejscu, wobec niemieckich pracowników samą możliwość przeniesienia produkcji można było wykorzystywać jako argument w negocjacjach płacowych.

\footnotetext{
${ }^{7}$ Niemieckie firmy inwestujące w Polsce są odpowiedzialne za boom w handlu między oboma krajami. W rezultacie udział Polski $\mathrm{w}$ handlu zagranicznym Niemiec $\mathrm{w}$ ostatnich latach był porównywalny z udziałem Włoch [Schmieg, 2019, s. 19].

${ }^{8} \mathrm{O}$ tym, jak bardzo inwestycje zagraniczne zwiększyły swobodę manewru pracodawców, a szczególnie wielkich pracodawców, informuja między innymi liczby. Na przykład: sto największych firm niemieckich zmniejszyło zatrudnienie w kraju o blisko 6\% między 1986 i 1996 rokiem, podczas gdy liczba zatrudnionych przez nie pracowników łącznie, to jest w kraju i zagranica, wzrosła o ponad $10 \%$ Jackson, 2003, s. 289].
} 
Z tych ustaleń uważny czytelnik może wyciagnąć wniosek, że to dzięki przechwytywaniu nakładów przemysł dóbr wymiennych mógł pozwolić sobie na podnoszenie płac szczególnie cenionym pracownikom bez szkody dla konkurencyjności cenowej swoich produktów9. Ciężar obniżania płac (i kosztów) spoczywał na innych sektorach gospodarki niemieckiej. Nie bez znaczenia był także dynamiczny wzrost transakcji z regionem wschodnioeuropejskim i korzyści wynikające ze stosunkowo niskich cen zagranicznych dostawców oraz stosunkowo niskich kosztów pracy w niektórych krajach, gdzie realizowano inwestycje niemieckie. Biorąc pod uwagę wymienione efekty dystrybucyjne, można wytłumaczyć paradoks niemieckiego przemysłu dóbr wymiennych, który utrzymuje konkurencyjność przy stosunkowo wysokich i rosnących płacach. Wynika to z tego, że obniżane są innego rodzaju koszty, między innymi dzięki „duszeniu” płac poza sektorem.

W literaturze spotyka się też pogląd, że utrzymanie konkurencyjności było możliwe dzięki reformom Hartza z 2003 i 2004 roku, które - jak można sądzić miały znaczenie w tym sensie, że czyniąc stan bezrobocia bardziej uciązliwym, wzmagały „uważność" pracowników i związków zawodowych na propozycje obniżek płac ze strony pracodawców i umożliwiały je przy mniejszym ryzyku otwartego konfliktu. Zmiany podstawowego wskaźnika konkurencyjności wskazywałyby jednak na brak związku między poprawą konkurencyjności i wspomnianymi reformami. Poprawa konkurencyjności w postaci konsekwentnie spadających jednostkowych kosztów pracy (w ujęciu „produkt finalny”) postępowała od połowy lat 90., czyli zanim wdrożono omawiane reformy, co pokazuja w artykule Dustmann i współpracownicy [2014, s. 158, rysunki: 4A, 4B]. Na dodatek jednostkowe koszty pracy (w wyrażeniu nominalnym) w kilka lat po reformach Hartza zaczęły rosná́ [Priewe, 2018, s. 94, wykres A9].

Z powyższych analiz i wyliczeń dowiadujemy się, że przynajmniej pracodawcy funkcjonujący w ,wystawowych" branżach niemieckiego przemysłu dobrze sobie radzą. Inaczej rzecz się przedstawia z perspektywy pracodawców w innych sektorach. Tej implikacji analizy efektów dystrybucyjnych Dustmann i współautorzy nie rozwijaja, natomiast dla nas stanowi ona podstawę do dalszych rozważań. Zarówno pracodawcy spoza „eksponowanych” branż, jak i rządzący politycy muszą stawić czoło problemowi niskiego zatrudnienia i postępującego zubożenia pracujących. W sumie można zgodzić się z opinią, że konkurencyjność przemysłu niemieckiego nie jest obecnie problemem. To jednak nie oznacza, że nie jest ona zagrożona z powodu presji na świadczenia społeczne, która może usztywniać bądź podnosić pozapłacowe koszty pracy w kraju.

\footnotetext{
${ }^{9}$ Nierówności płacowe ujawnia dodatkowa dezagregacja na centyle według dochodów. W przemyśle dóbr wymiennych (indeksowany) wzrost płac realnych różnie rozkładał się pomiędzy różne grupy dochodowe. Płace rosły w grupie pracowników średnio i dobrze zarabiających, spadały natomiast place na najniższch szczeblach dochodów [Dustmann i in., 2014, s. 155, rysunek 3].
} 


\section{Składki emerytalne jako część pozapłacowych kosztów pracy i udział stron w ich finansowaniu}

Wynagrodzenia to główny, lecz nie jedyny składnik kosztón pracy. Na pozapłacowe koszty składają się przede wszystkim składki na ubezpieczenia społeczne i zdrowotne, które są odliczane od płacy brutto.

Pozapłacowe koszty pracy są w Niemczech stosunkowo wysokie. Obciążenie płac brutto składkami na ubezpieczenia społeczne łącznie w połowie lat 90. osiagnęło historycznie rekordowy poziom i w zasadzie nie spada (tabela 1). W latach 2007-2008 łączna składka z tytułu ubezpieczeń społecznych, wpłacana w imieniu pracownika i pracodawcy, odniesiona do płacy brutto, zmalała do $40 \%$ [Hinrich, 2010, tabela 2.1, s. 52].

TABELA 1

Składki na ubezpieczenia społeczne jako procent płacy brutto

\begin{tabular}{|c|c|c|c|c|c|}
\hline Rok & $\begin{array}{c}\text { Składki } \\
\text { emerytalne }\end{array}$ & Lącznie & Rok & Składki emerytalne & Lącznie \\
\hline 1957 & 14 & $\mathbf{2 3 , 8}$ & 1998 & 20,3 & $\mathbf{4 2 , 1}$ \\
\hline 1973 & 18 & $\mathbf{2 8 , 9}$ & 1999 & 19,5 & $\mathbf{4 1 , 3}$ \\
\hline 1985 & 19,2 & $\mathbf{3 5 , 1}$ & 2000 & 19,3 & $\mathbf{4 1 , 1}$ \\
\hline 1995 & 18,6 & $\mathbf{3 9 , 9}$ & 2001 & 19,1 & $\mathbf{4 0 , 9}$ \\
\hline 1996 & 19,2 & $\mathbf{4 1 , 1}$ & 2002 & 19,1 & $\mathbf{4 1 , 3}$ \\
\hline 1997 & 20,3 & $\mathbf{4 1 , 9}$ & 2003 & 19,5 & $\mathbf{4 2 , 0}$ \\
\hline
\end{tabular}

Źródło: [Streeck, Trampusch, 2005, s. 177, tabela 1].

Podobny wniosek można wyciagnąc z porównań międzynarodowych, na przykład biorąc pod uwagę składki na ubezpieczenia społeczne (powiększone o zaliczkę na podatek dochodowy) jako odsetek całkowitych kosztów pracy i kiedy przyjmiemy jako punkt odniesienia średnie wskaźniki dla krajów wysoko rozwiniętych. Mianowicie, w 2015 roku wskaźnik dla Niemiec (49,4\% wg [Mazurek-Chwiejczak, 2016, s. 171, tabela 1]) wyraźnie przewyższał poziom średniej UE-21 (41,8\% wg [Mazurek-Chwiejczak, 2016 s. 170, rysunek 3]). W dłuższym okresie z kolei średnia dla UE-21, oscylująca w latach 2000-2015 wokół 42\%, znajdowała się znacznie powyżej średniej OECD, oscylującej wokół 36\% w tym samym okresie. Ma to znaczenie dla tematu, gdyż w tej drugiej grupie dominujące wagi należą do USA i Japonii, ważnych konkurentów Niemiec. Relacje te obrazują również inne dane OECD wykorzystujące jako wspólny mianownik nie płacę brutto, lecz produkt krajowy brutto (tabela 2). Wskaźnik dla Niemiec jest jednym z najwyższych w OECD (i jest wyraźnie wyższy niż w Polsce). Do czasu ujawnienia kryzysu w 2008 wykazywał tendencję spadkowa, która pod presją Wielkiej Recesji uległa zahamowaniu w latach następnych. 
TABELA 2

Składki na ubezpieczenia społeczne jako procent PKB

\begin{tabular}{|l|c|c|c|c|c|c|c|c|c|c|}
\hline & $\mathbf{2 0 0 0}$ & $\mathbf{2 0 0 1}$ & $\mathbf{2 0 0 5}$ & $\mathbf{2 0 0 8}$ & $\mathbf{2 0 0 9}$ & $\mathbf{2 0 1 1}$ & $\mathbf{2 0 1 3}$ & $\mathbf{2 0 1 5}$ & $\mathbf{2 0 1 6}$ & $\mathbf{2 0 1 8}$ \\
\hline Niemcy & 14,1 & 13,9 & 13,5 & 12,9 & 13,9 & 13,8 & 13,9 & 13,9 & 14,1 & 14,4 \\
\hline OECD & $\mathbf{8 , 6}$ & $\mathbf{8 , 7}$ & $\mathbf{8 , 6}$ & $\mathbf{8 , 6}$ & $\mathbf{8 , 9}$ & $\mathbf{8 , 9}$ & $\mathbf{9 , 0}$ & $\mathbf{9 , 0}$ & $\mathbf{9 , 1}$ & $\mathbf{9 , 4}$ \\
\hline Polska & 13,0 & 13,4 & 12,1 & 11,2 & 11,1 & 11,1 & 12,2 & 12,4 & 12,7 & 13,1 \\
\hline
\end{tabular}

Źródło: [www 1].

Składki emerytalne stanowią zdecydowanie największą część obciążeń płacy brutto w Niemczech (podobnie jak w Polsce). Jak wynika z tabeli 1, obciążenie płac $z$ tego tytułu wzrosło i stanowi równowartość jednej piątej płacy brutto. To skłania do przyjrzenia się temu składnikowi kosztów pracy ze szczególną uwaga.

Niezbędna wydaje się tu podstawowa charakterystyka systemu ubezpieczeń emerytalnych oraz krótka informacja o nowych rozwiazzaniach instytucjonalnych, które prowadziły do systemowych zmian. Zgodnie z przyjętym na wstępie założeniem, prezentacja będzie prowadzona $z$ uwagi na interesy pracodawców, a więc także - producentów bardziej lub mniej bezpośrednio związanych z „wystawowymi” branżami niemieckiego przemysłu. Zarys całości wyłoni pozostałe strony „kontraktu" emerytalnego i pozwoli pokazać efekty dystrybucyjne wzbudzone reformowaniem systemu.

System zabezpieczeń emerytalnych $\mathrm{w}$ Niemczech tradycyjnie wspiera się na dwóch filarach: na podstawowych i zarazem przymusowych ubezpieczeniach oraz na dobrowolnych ubezpieczeniach organizowanych w ramach zakładów pracy. Prywatni pracodawcy obowiązani sa uczestniczyć w systemie ustawowo gwarantowanych emerytur, powołanym reforma Adenauera z 1957 roku (Gesetzversicherungrenten - GVR), który dotyczy ponad 80\% zatrudnionych w gospodarce. Obowiazkowe ubezpieczenie emerytalne w tym segmencie pochłaniało jeszcze na początku XXI wieku co miesiąc 19,5\% płacy brutto, a jego ciężar był rozłożony równo pomiędzy pracownika i pracodawcę [The handbook of West..., 2007]. Poczynając od programu rządu Gerharda Schroedera z końca lat 90., obniżenie łącznych (przymusowych) składek na zabezpieczenie społeczne stało się „politycznym dogmatem" [Sozialstaat Deutchland..., 2010, s. 277-278; Mierzejewski, 2015]. $\mathrm{Z}$ innych segmentów systemu pochodzą dodatkowe świadczenia emerytalne i tam ubezpieczenia są dobrowolne. W przemysłach „wystawowych” daje się zauważyć stosunkowo wysokie dobrowolne zaangażowanie pracodawców w zakładowe plany emerytalne (betrieblichen Alterversorgung - bAV), które rozwijają się co najmniej od lat 70. XX w. W tradycyjnych formach zakładowych ubezpieczeń emerytalnych pracowników (Direktzusage, Unterstuezungskasse) składki pokrywają pracodawcy. O tym, że znaczenie zakładowych ubezpieczeń emerytalnych w Niemczech było zupełnie inne niż w Polsce, przekonuje to, że z góra połowa pracowników sektora prywatnego była ubezpieczona $\mathrm{w}$ tym segmencie [The handbook of West..., 2007]. $\mathrm{Na}$ tych dwóch filarach system opierał się co najmniej przez kilka powojennych dekad i oba, zgodnie z powszechną opinią, miały charakter ubezpieczeń społecz- 
nych. Dopiero reforma z 2001 roku wprowadziła novum, którym w Niemczech były osobiste, „prywatne” ubezpieczenia emerytalne. Etapy reform były wyznaczane przez kolejne modyfikacje prawa emerytalnego oraz innowacyjne ustawy: tak zwane reformy Riestera w 2001 roku (w ramach Agenda 2010), tak zwaną reformę Ruerupa w 2004 roku oraz ustawę o emeryturach zakładowych (Betriebsrentengesetz) w 2007 roku [The handbook of West..., 2007]. W 2018 roku weszła w życie tzw. ustawa wzmacniająca emerytury pracownicze (Betriebsrentenstaerkungsgesetz). W rezultacie wprowadzono system indywidualnego oszczędzania z funduszami, mocno subsydiowany przez państwo, a możliwości dodatkowego oszczędzania na emeryturę w ramach zakładowych ubezpieczeń zostały znacznie rozszerzone ${ }^{10}$.

Czy opisane zmiany przyniosły oczekiwany przez pracodawców efekt ograniczenia kosztów związanych z ubezpieczeniami emerytalnymi pracowników? Postaramy się pokazać, że w tym względzie zmiany w segmencie dodatkowych, dobrowolnych ubezpieczeń emerytalnych miały większe znaczenie niż reformy segmentu, w którym rządzi przymus państwowy.

Omówione formy odkładania dochodu na fundusze emerytalne różnie oddziałują na pozapłacowe koszty pracy. Obowiązek takich transferów narzucony prywatnym przedsiębiorstwom (w Niemczech $w$ ramach GVR) obciąża płace brutto, inaczej - wymusza większe łączne rezerwy utrzymywane w przedsiębiorstwie na rzecz pracowników. Podobny efekt ma dobrowolne obciążenie pracodawcy (w Niemczech w różnym stopniu w różnych formach zakładowych ubezpieczeń). Natomiast formy dobrowolnego uczestnictwa pracowników w programach emerytalnych (w Niemczech w niektórych formach bAV oraz w ramach „Riester-Rente”) oznaczają zgodę pracownika na pomniejszenie płacy netto o wartość składki, inaczej - nie rodzą zobowiązań pracodawcy z tytułu ubezpieczeń emerytalnych. Tymczasem pojęcie „pozapłacowych kosztów pracy” ma zastosowanie jedynie wtedy, kiedy zobowiązania tego typu powstają.

Modyfikacje zasad ustawowo gwarantowanych emerytur doprowadziły między innymi do obniżenia stopy obowiązkowej składki emerytalnej. Wysokość stopy, według której oblicza się składki emerytalne, nie jest obojętna ani dla pracowników, ani dla firm, które dają im zatrudnienie. Określa ona bowiem środki, które w tym celu musi zarezerwować pracodawca oraz część płacy brutto, o która zostanie pomniejszone wynagrodzenie pracownika przy wypłacie. Ponieważ w tym filarze składka jest zobowiązaniem pracodawców, obniżenie stopy oznacza dla nich uwolnienie pewnych środków, które nie musza już być „zamrożone” na potrzeby ubezpieczenia. Niemniej wspomniana obietnica wyborcza partii Schroedera doprowadziła do niewielkiego obniżenia obciążenia płacy składkami (tabela 1). Sukcesywne obniżki stopy w sumie w ciagu kolejnych 20 lat złożyły się na niecały punkt procentowy ${ }^{11}$. Po latach reformowania segmentu publicznego najważniejszą zmianą okazała się nie

\footnotetext{
10 Zainteresowanych ewolucją zabezpieczeń emerytalnych w Niemczech odsyłamy do lektury, np. Hemerijck, Eichhorst [2010], Hausermann [2010].

11 Od 1 stycznia 2018 r. stopa obowiązkowej składki emerytalnej wynosi 18,6\% [www 2].
} 
ta ulga, lecz wydłużenie wieku, w którym nabywa się prawa emerytalne w Niemczech (z 65 do 67 lat).

Jako wyraźnie korzystne dla pracodawców można ocenić zmiany, które zachodzą poza segmentem obowiązkowych ubezpieczeń emerytalnych, to jest za sprawa nowych form zakładowych planów emerytalnych oraz dzięki zainicjowaniu „osobistych" ubezpieczeń emerytalnych. Indywidualne oszczędzanie na starość z funduszami, upowszechnione dzięki reformom Riestera, z definicji wyklucza udział pracodawców; składki pochodzą wyłącznie z wkładu ubezpieczonego ${ }^{12}$. Natomiast nowe ustawy o emeryturach zakładowych pozwalają na ograniczanie udziału pracodawców ogółem w zakładowych ubezpieczeniach emerytalnych (tabela 2).

Pracownicze programy emerytalne mogą być finansowane wyłącznie przez pracodawców, kiedy ci pragna przyciagnać i utrzymać wysoko kwalifikowaną siłę roboczą. Taka zasada rządziła tradycyjnie w wielkich niemieckich zakładach pracy, zwłaszcza w proeksportowych gałęziach przemysłu przetwórczego, które charakteryzowała orientacja na specyficzne kwalifikacje pracowników, a szczególnie w branży chemicznej oraz w przemyśle przetwarzania metali [Wiss, 2011, s. 260]. W wyniku reform owe tradycyjne formy emerytalnych planów pracowniczych (Direktzusage, Unterstuetzungskasse) zostały uzupełnione o takie programy, które umożliwiają udział pracownika (Direktversicherung, Pensionskasse, Pensionsfonds i in.) [Wiss, 2011, s. 193, tabela 18]. W rezultacie w tym segmencie ubezpieczeń emerytalnych wyraźnie zmalał udział pracodawców na rzecz mieszanego finansowania, to jest wspólnie z pracownikami.

TABELA 3

Zakładowe ubezpieczenia emerytalne w Niemczech: udział zakładów pracy $\mathrm{z}$ sektora prywatnego według formy finansowania

\begin{tabular}{|l|l|l|l|l|}
\hline \multicolumn{1}{|c|}{ Finansowanie } & $\mathbf{2 0 0 1}$ & $\mathbf{2 0 0 3}$ & $\mathbf{2 0 0 5}$ & $\mathbf{2 0 0 7}$ \\
\hline Pracodawca & $54 \%$ & $42 \%$ & $40 \%$ & $38 \%$ \\
\hline Pracownik & $26 \%$ & $30 \%$ & $32 \%$ & $32 \%$ \\
\hline Mieszane & $27 \%$ & $40 \%$ & $40 \%$ & $42 \%$ \\
\hline
\end{tabular}

Uwaga: Suma udziałów może wynieść więcej niż 100\%, ponieważ w zakładach pracy może być przyjęta więcej niż jedna reguła.

Źródło: [Wiss, 2011, s. 200, tabela 19], według danych BMAS.

Wspomnianym zmianom towarzyszy znaczne finansowe wsparcie ze strony państwa, szczególnie w segmencie ubezpieczeń indywidualnych. Wydatki na dopłaty do „produktów Riestera” (polisy na życie, papiery wartościowe, nieruchomości) do 2009 roku skumulowały się do kwoty ponad 6 miliardów euro, natomiast ulgi podatkowe $z$ tytułu dodatkowych ubezpieczeń emerytalnych osiagnęły $0,8 \% \mathrm{PKB}$

12 Podobnie w przypadku ubezpieczeń zdrowotnych od 2006 r. finansowanie zasiłku chorobowego opiera się wyłącznie na wpłatach ubezpieczonego. 
[Wiss, 2011, s. 201]. Również w segmencie zakładowych planów emerytalnych wraz z nowymi formami finansowania wprowadzono możliwość dopłat $\mathrm{z}$ budżetu państwa, podtrzymując przy tym uprzywilejowanie podatkowe [Wiss, 2011, s. 200, tabela 20].

$\mathrm{Na}$ przykładzie Niemiec można zaobserwować, jak wraz ze zwiększaniem zasięgu dobrowolnych ubezpieczeń emerytalnych zmienia się rozkład udziału trzech stron emerytalnego „kontraktu” w finansowaniu przyszłych świadczeń. Generalnie składki ubezpieczeniowe wpływaja do budżetu emerytalnego ze strony pracownika lub ze strony pracodawcy. Ponadto w celach społecznych i politycznych angażowane są fundusze budżetowe państwa. Efekty dystrybucyjne reform uwidaczniaja się w zmianie rozkładu obciążeń kosztami składek między tymi stronami. Reformy sprzyjające rozbudowie zakładowych ubezpieczeń społecznych w firmach prywatnych oraz rozwój indywidualnych ubezpieczeń emerytalnych i zdrowotnych z funduszami inwestycyjnymi zostały zaprojektowane tak, aby oszczędzić pracodawcom zwiększenia ich udziału w finansowaniu ubezpieczeń. Zarazem powiększyły udział pracowników w segmencie emerytur pracowniczych, a w segmencie emerytur indywidualnych zapewniły zaangażowanie finansów publicznych w formie dopłat i ulg podatkowych na niespotykaną skalę. Z punktu widzenia państwa koszty $i$ dochody utracone $z$ tytułu dodatkowych emerytur sa znaczne. Nowa struktura obciążeń uczestników systemu zabezpieczeń emerytalnych chroni producentów przed dalszym wzrostem kosztów pozapłacowych. Rozbudowa dobrowolnych ubezpieczeń obciążyła przede wszystkim pozostałe strony „kontraktu” emerytalnego.

\section{Podsumowanie}

Gałęzie gospodarki, które decydują o konkurencyjności międzynarodowej Niemiec, w szczególności „wystawowe” branże przemysłu, korzystają z efektów dystrybucyjnych. W tym sensie zajmuja pozycję uprzywilejowaną wśród sektorów gospodarki. Cieszą się też względami w polityce reform emerytalnych, których efekty dystrybucyjne okazały się ,,bezkosztowe”, zwłaszcza dla pracodawców w proeksportowych gałęziach przemysłu przetwórczego.

Analiza zdezagregowanych kosztów pracy wykazuje, że w przemyśle dóbr wymiennych płace realne rosły. Oprócz zwiększenia kosztów płacowych oznacza to wzrost składek emerytalnych i innych pozapłacowych składników kosztów pracy obliczanych od tej podstawy. Pomimo tego sektor utrzymywał cenowa przewage konkurencyjna, o czym świadczą indeksy cen w eksporcie. Analiza uzmysławia, że jednym ze sposobów na neutralizowanie negatywnego efektu rosnących płac i stosunkowo wysokich pozapłacowych kosztów w przemysłach „wystawowych” jest przechwytywanie nakładów zarówno z innych sektorów gospodarki narodowej, jak i z zagranicy. Tym sposobem aktywność gospodarcza związana z przemysłem i z wymianą zagraniczną była chroniona przed trendem ograniczania wzrostu realnych płac bardziej niż aktywność w sektorach dóbr niewymiennych. 
$\mathrm{Na}$ symptomatyczne przesunięcia nakładów wskazuje również analiza pozapłacowych kosztów pracy wynikających z ubezpieczeń emerytalnych pracowników. Wydaje się, że pracodawcy są grupa chroniona przez reformy emerytalne, które próbuja rozwiązać problem niedostatku dochodów względem wypłat w budżecie emerytalnym. Polityka reform doprowadziła w skali kraju do niewielkiego ograniczenia obowiązkowych kosztów. W segmentach emerytur dodatkowych względem emerytur ustawowo gwarantowanych nowe rozwiązania znacznie zwiększają możliwości finansowania świadczeń ze składek ubezpieczonych (głównie pracowników) oraz dzięki wkładowi finansowemu państwa. Składki pracowników w tych dobrowolnych segmentach nie sa postrzegane jako pozapłacowe koszty pracy, a tym bardziej koszty ponoszone przez budżet nie powiększają tej statystycznej kategorii. W rezultacie nie powiększa się obciążenie funduszy przedsiębiorstw z tytułu ubezpieczeń emerytalnych, natomiast ciężar uzupełnienia przyszłych podstawowych emerytur o dodatkowe świadczenia został przesunięty na płace netto oraz na finanse publiczne. W podmiotowej strukturze nakładów dokonało się zatem przesunięcie między głównymi uczestnikami systemu zabezpieczeń: od pracodawców do pracowników i państwa.

\section{Literatura}

Dustmann Ch., Fitzenberger B., Schoenberg U., Spitz-Oener A., 2014, Od chorego cztowieka Europy do ekonomicznej supergwiazdy: odradzajaca sie gospodarka Niemiec, „Gospodarka Narodowa”, nr 6(274), s.149-172, DOI: 10.33119/GN/100903.

Hausermann S., 2010, The politics of welfare state reform in continental Europe. Modernization in hard times, Cambridge University Press, New York.

Hemerijck A., Eichhorst W., 2010, Whatever happened to the Bismarckian welfare state? From labor shedding to employment-friendly reforms, [in:] Long goodbye to Bismarck? The politics of welfare reforms in continental Europe, Palier B. (ed.), Amsterdam University Press, Amsterdam.

Hinrich K., 2010, A social insurance state withers away. Welfare state reforms in Germany or: attempts to turn around in a Cuel-De-Sac, [in:] Long goodbye to Bismarck? The politics of welfare reforms in continental Europe, Palier B. (ed.) Amsterdam University Press, ProQuest Book Central, Amsterdam.

Jackson G., 2003, Corporate governance in Germany and Japan: liberalization pressures and responses during the 1990s, [in:] The end of diversity? Prospects for German and Japanese capitalism, Streeck W., Yamamura K. (eds.), Cornell University Press, Ithaca and London.

Mazurek-Chwiejczak M., 2016, Opodatkowanie dochodów z pracy w państwach OECD studium porównawcre, „Przedsiębiorstwo i Region”, nr 8, s. 166-185, DOI: 10. 15584/pir.2016.8.15.

Mierzejewski A., 2015, Paradigm shift: the reform of the German public pension system in 2001, „Journal of Policy History”, vol. 27, iss. 4, pp. 695-721, DOI: 10.1017/ S0898030615000317. 
Owsiak S., 2005, Finanse publične. Teoria i praktyka, Wydawnictwo Naukowe PWN, Warszawa

Płóciennik S., 2012, Od reńskiego do tabskiego kapitalizmu. Systemowe skutki reform ubezpieczeń spotecznych w RFN w latach 2000-2008, Oficyna Wydawnicza Atut - Wrocławskie Towarzystwo Oświatowe, Wrocław.

Priewe J., 2018, A time bomb for the euro? Understanding Germany's current account surplus, „IMK Studies”, vol. 59, pp. 1-99.

Schmieg E., 2019, Economy, [in:] Germany, Poland and the future of transatlantic community, Balcer A., Blusz K., Schmieg E. (eds.), WiseEuropa and Konrad Adenauer Stiftung, Warszawa.

Sozialstaat Deutchland. Gesichte und Gegenwart, 2010, Becker U., Hockerts H.G., Tanfelde K., Friedrich Ebert Stiftung, Verlag J.H.W. Dietz Nachf. GmbH, Bonn. Stiglitz J.E., 2004, Ekonomia sektora publicznego, Wydawnictwo Naukowe PWN, Warszawa (oryginalnie: Stiglitz J., 2000, Economics of the public sector, W. W. Norton \& Co., New York, London).

Streeck W., Trampusch C., 2005, Economic reform and the political economy of the German welfare state, „German Politics”, vol. 14, iss. 2, pp. 174-195, DOI: 10.1080/0964 4000500154490.

The handbook of West European pension politics, 2007, Immergut E., Anderson K., Schultze I. (eds.), Oxford University Press, Oxford.

Wiss T., 2011, Der Wandel der Alterssicherung in Deutschland. Die Rolle der Sozialpartner, VS Verlag fuer Sozialwissenschaften, Wiesbaden.

www 1, https://data.oecd.org/tax/social-security-contributions.htm [data dostępu: 11.12.2019].

www 2, https://www.lohn-info.de/sozialversicherungsbeitraege2018.html [data dostępu: 24.03.2019]. 